\title{
Herd Health Management on Dairy Farm: An Overview
}

\author{
Berhanu Butako ${ }^{1 *} \quad$ Naod Tomas ${ }^{2}$ \\ 1.Sodo zuria district Veterinary Clinic, Southern Ethiopia, Ethiopia \\ 2.School of Veterinary Medicine, Wolaita Sodo University, Ethiopia
}

\begin{abstract}
SUMMARY
Herd health management is a method to optimize health, welfare and production in a population of dairy cows, through the systematic analysis of relevant data and through regular objective observations of the cows and their environment Industrialization of animal farming and increasing international market competition has led to selective breeding of high producing cows and consequence of this development, however, was higher susceptibility to disease. As a result of this, attention shifted from curing single animals to prevention of disease on herd level. Bio-security is a program used to prevent the introduction pathogens from external sources on farms, as well as the spread of such diseases once they have entered the farm. The monitoring is an essential part of programs to achieve and maintain a good udder health on dairy farms in the long term. It is necessary for routine evaluations of the herd health and performance status, the continuous verification of the effectiveness of actions taken to improve the herd status and, the early identification of emerging problems. Bovine teat condition score can be used to assess the effects of milking management, milking equipment or environment on teat tissue and the risk of new intramammary infections. Timely claw trimming can improve cow mobility (locomotion) and prevent lameness. Developing science-based recommendations for different aspects of the monitoring of the udder health on dairy farms, improving management practices and biosecurity are very important.
\end{abstract}

Keywords: Bio-security, Dairy farms, Herd

DOI: $10.7176 / \mathrm{JBAH} / 9-1-09$

\section{INTRODUCTION}

Over the past decades several changes have taken place in dairy farming. Industrialization of animal farming and increasing international competition has led to selective breeding of high producing cows. Consequence of this development, however, was higher susceptibility to disease (DeKruif and Opsomer, 2004). As a result of this, attention shifted from curing single animals to prevention of disease on herd level (LeBlanc et al., 2006).

Herd health is a method to optimize health, welfare and production in a population of dairy cows, through the systematic analysis of relevant data and through regular objective observations of the cows and their environment, such that informed, timely decisions are made to adjust and improve herd management over time (Green, 2012). This process is therefore a continuous one, involving regular contact with the dairy farm staff and a methodical analysis of the farm data, so that all aspects of the health and welfare of the cattle are reviewed frequently. It is this regular contact that is of critical importance to the success of any herd health service, as it not only helps develop a close working relationship with the farm staff, but also allows for constant monitoring and re-evaluation of the farm's performance, which is particularly important when judging the successes or failures of management decisions. Herd health is not to be confused with one-off investigations or herd health plans, which, while often useful, are quite different to regular herd health management. The overriding delivery tool for delivering animal health and welfare benefits, and improved food safety, must be effective farm health planning, based on the achievement of outputs (Veterinarian development council, 2012; More, 2008).

Dairy farming is an economic process where resource factors are turned into income (production) factors. Diseases cause substantial economic loss in dairy herds. Herd health and productivity management has become a core business of modern veterinary practices in developed countries. The unit of concern is the herd as opposed to the sick cow. This is because the farmer earns his income through healthy cows and loses money via sick cows (James et al., 2013). The significance of this review is to give an emphasis on prevention of herd health on dairy farm by application of bio-security program. Therefore, the aim of this paper is to give insight on current status of herd health on dairy farms by designed bio-security program and monitoring of the udder health

\section{HERD HEALTH MANAGEMENT ON DAIRY FARM}

\section{Biosecurity}

Biosecurity is a program with a series of management practices designed to minimize or prevent and control the introduction of infectious disease agents onto a farm, spread within a farm production operation, and export of these disease agents beyond the farm that may have an adverse effect on the economy, environment and human health. There are various practical methods used to detect strong points and points for improvement, organize a farm visit and interpret farm performance (Canadian Food Inspection Agency, 2013; Ellen et al., 1914; Faust et al., 2001; Noordhuizen, 2012; Stankovic et al., 2016; Tatiana, 2017). 


\section{How to design a biosecurity program}

According to Canadian Food Inspection Agency (2013), and Noordhuizen (2012), there are five steps needed to take when designing a biosecurity programme for use on farm: Conduct a written, critical inventory of infectious diseases that are relevant to the farm. Take into account the geography, soil type, housing, animals, people and visitors, transportation means; With the farmer, identify the most important infectious diseases already present in the herd; Identify the most important infectious diseases that are not yet present on the farm but present a threat; Conduct a diagnostic herd evaluation (animals and environment) to determine the level of risk for the transmission of selected disease pathogens. Formulate goals for the biosecurity programme: for example a 5\% reduction in the prevailing clinical mastitis incidence per year; illustrate the biosecurity programme and implement it. Work together with the other people working on/for the farm, including professional consultants to try to ensure compliance and the programme must be updated at least annually.

\section{Laying the foundation of biosecurity Plan}

A farm biosecurity plan identifies the biosecurity practices that are designed to manage the risks on farm. Consideration should be given to farm layout, facility design and operational practices, along with the diseases of concern and their modes of transmission. All of these factors influence the risk assessment of farm and determine which practices will be most useful in mitigating those risks. Developing a farm-level biosecurity plan is a team effort between farmer and veterinarian and will be individual to each farm. For dairy producers, a biosecurity plan aims to achieve three general goals. Exclude: prevent the introduction of disease-causing organisms (pathogens) to cattle on dairy farms; Manage: prevent the spread of pathogens among cattle within a dairy farm; Contain: prevent the spread of pathogens between dairy farms or from dairy farms to other animal populations (Canadian Food Inspection Agency, 2013; Noordhuizen, 2012; Leppala, 2016).

\section{Create a farm diagram}

The farm layout and facility design can have a significant impact, either positively or negatively, on the biosecurity risks on farm. Indeed, the farm provides the backdrop in which biosecurity must operate and directly influences both the need for certain biosecurity practices as well as the practicality of implementing them. Consideration should also be given to creating a second diagram specifically of the production area(s), indicating: milking parlour and/or tie stalls, maternity pen, milking cow housing area, dry cow housing, heifer housing, calf pen/hutches, isolation area, laneways/walkways, hospital pen / treatment area, cleaning and disinfection facilities, loading chute, chemical storage, and employee area. It may be possible to include all of this information on one diagram, depending on the complexity of the farm (Canadian Food Inspection Agency, 2013; Cook, 2013; Noordhuizen, 2012; Stankovic et al., 2016).

\section{Designate biosecurity zones}

All components of a dairy farm should not be considered at equal risk relative to biosecurity concerns. Therefore, once the farm layout and facility design has been considered and the farm diagram(s) created, biosecurity zones can be established on farm. The idea of zones is that they contain areas of similar biosecurity risk, and moving between them, generally through a predetermined access point, requires care and specific practices to avoid cross-contamination. Relative risk zones help to conceptualize the biosecurity plan as it applies to animals, facilities and management. The key idea is to concentrate the majority of efforts in identified high-risk zones (FAO and IDF, 2011; Noordhuizen, 2012).

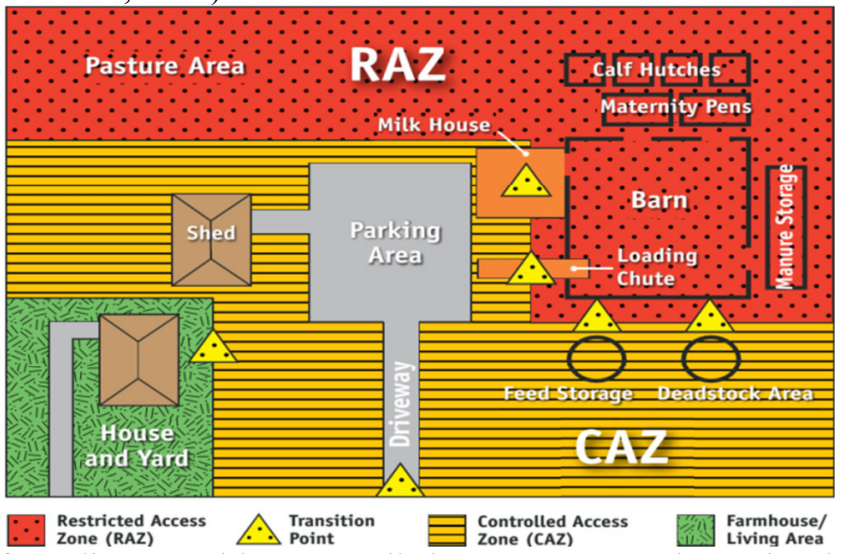

Figure 1: Sample dairy farm diagram with a Controlled Access Zone and Restricted Access Zone (Canadian Food Inspection Agency, 2013).

Transition points are points at which animals, people, tools, equipment and/or vehicles could be expected to 
enter or leave a zone, and at which biosecurity practices should be applied. At all transition points, the key concept is to leave behind, or clean and disinfect, any materials, clothing, equipment, or other fomites when moving from one risk zone to another. According to Canadian Food Inspection Agency (2013), examples of common transition points are: Milk house: Often the most-used access point to the RAZ, and also an area frequently visited by milk pick-up personnel, inspectors and other service providers; Loading chute: Creates an opportunity for cattle and people handling them to commingle in both the CAZ and the RAZ, especially if it leads directly to the active production area, and for the two areas to be contaminated by the movement of cattle between the two zones; Feed storage: Requires access from both the CAZ (e.g. by feed delivery personnel and farm workers who are loading up feed produced on the farm), and from the RAZ (e.g. for provision of feed stores to cattle in the barn and elsewhere in the production area) creating multiple transition points; Dead stock storage: May require access from both the RAZ and the CAZ, and have multiple transition points; Manure storage: May be a multiple-access area, depending on the disposal procedures for manure on each farm. The area may be enclosed within the RAZ, as shown in the diagram, or it may be a transition point, if manure is disposed of away from the production area. Setting up these zones contributes to the organized and effective implementation of biosecurity practices.

\section{Assign risk areas and outline movement pathways}

Within the Restricted Access Zone (RAZ) there are groups of animals that are more susceptible to disease, specifically in the calf pens and the maternity area. There are also groups of animals, either in the isolation area or hospital pen, which are more likely to carry disease and pose a higher risk of disease transmission. Preparing a list of these areas and pathways, and/or locating them on a sketch of the production area will be useful in illustrating where there are areas of greater or lesser risk for disease transmission, and therefore where biosecurity best management practices must carefully be considered(Canadian Food Inspection Agency, 2013). Movement of people, equipment and tools occurs between these areas on a daily basis. All movement poses a risk of contamination of the pathways and may ultimately lead to disease transmission between groups of cattle. It is crucial to consider the physical location of various groups of animals. Their proximity to others, their location relative to traffic barriers, and the air movement in the area, all impact the risk of disease transmission. This information can be used to develop a plan for the movement of people, animals and equipment that minimizes the risk of disease transmission (Cook, 2013; FAO and IDF, 2011; Leppala, 2016).

\section{Establish goals for production and animal health}

The level of biosecurity implemented on operation will depend on goals for production and animal health. It is imperative to establish goals before building biosecurity plan. Many factors will influence these goals including the purpose of herd (commercial versus show herd), and the products sold from your dairy farm (milk, meat/cull cattle, calves, replacement heifers, milk cows, embryos and semen) (Canadian Food Inspection Agency, 2013; Leppala, 2016).

\section{Determine risk tolerance}

Biosecurity is essentially a process of managing risk. Veterinarian must determine what level of risk on farm is willing to assume or accept and then design biosecurity plan accordingly to ensure that mitigation measures maintain the risk at an appropriate threshold. Again, many factors will influence the acceptable level of risk for farm, including what products are sold or may be sold in the future (e.g. milk, meat, breeding animals, semen and embryos), as well as the resources available to devote to biosecurity interventions(FAO and IDF,2011; Leppala, 2016).

\section{Complete a risk assessment for disease}

In order to effectively begin to develop a biosecurity plan to manage the risks on farm, it is important to complete a risk assessment for disease. Risk assessment is a way of determining the presence, distribution and severity of a given disease on farm. The basis for risk assessment is not to eliminate all risks, but to segregate risks into various levels to assist with informed decision making. Risk assessment helps to determine the specific factors that are most likely to lead to the introduction and spread of pathogens (FAO and IDF, 2011; Noordhuizen, 2012; Wallace, 2003).

\section{Building biosecurity plan}

According to Canadian Food Inspection Agency (2013), there are four strategies for building biosecurity plan: Animal health management; Animal additions and movement; Premises' management and sanitation; and Personnel, visitors, vehicles and equipment control. 


\section{HOUSING AND FLOOR SYSTEMS FOR DAIRY COWS \\ Housing systems for dairy cows}

The best way to fully utilize the genetic potential of dairy cows is to create an ideal environment, with the emphasis on cow comfort to optimize animal health and performance. Animal welfare is more than just feeding, taking care of animals and ensuring good health. It is essential that housing, feeding and general care are in balance with the needs of the animals. Besides this, the correct set-up of dairy housing and its components is of major importance with a view to the final results (House, 2011; Noordhuizen, 2012).

Dairy management systems span from tie-stalls, free-stalls, straw yards and pasture-based operations, and mixes between them. The concept of a tie-stall barn is that all activities are made in the same stall and free movement is restricted. The cows are tied to their laying area where the cows are able to stand and lie down, but not turn around (Phillips, 2010). Free-stall systems, also named cubicles systems (Europe), are barns with stalls separated with dividers. Cows can move freely between the resting, feeding and milking areas, where automatic gates often direct them. A straw yard is on the other hand an open area with deep bedding and undefined laying places. In pasture-based systems cows are fed on pasture most of their lactation and are moved back and forth to the milking, where the distance depends on herd size (House, 2011; Phillips, 2010).

\section{Floor system for dairy cows}

Cattle are evolutionary adapted to stand, walk and lay down on a variation of hard and soft foundations. Pasture is the natural habitat for cattle, which provides a large loafing area, a beneficial amount of claw wear, good traction, and a low presence of fecal bacteria. Free-stalls, named cubicles in Europe, is the most common dairy housing system in western countries and is associated with concrete alley floors. Floor properties are considered to be one of the most important welfare and health factor for dairy cow housing (Bergsten et al., 2015; Rushen and dePassille, 2009). Despite the aim of more freedom, free-stalls have been reported to increase the frequency of claw disorders and lameness in dairy cattle (Hultgren, 2002). One challenge with the free-stalls is therefore to design a proper floor system that is ergonomic for the animals i.e. slip-resistant, comfortable (Telezhenko et al., 2017) and promoting normal locomotion (Telezhenko and Bergsten, 2005).

The most common floor type in free-stalls for dairy cows is concrete floors because of its possibility for molding constructions, affordable prize, easiness to clean and durability (Telezhenko and Bergsten, 2005; Telezhenko et al., 2009). Newly installed concrete floors have a proper level of friction. However, the surface will become slippery over time due to chemical and mechanical degradation (DeBelie et al., 2000). Slippery floors will make cows act more carefully, which negatively affects locomotion (Rushen and dePassille, 2009), general activity (Haufe et al., 2009; Telezhenko et al., 2017) and social and sexual behaviors (Norberg, 2012; Platz et al., 2008). Furthermore, quick movements on slippery floors increase the risk of slipping and falling, which could generate severe injuries and fatality in worst cases (Whitaker et al., 2000). It is therefore common that dairy farmers restore their slippery concrete floors by grooving (Phillips and Morris, 2001). Grooving provides more friction, which supports traction (Phillips and Morris, 2001; Telezhenko et al., 2017); however, if the floor becomes too abrasive it could result in an unfavorable claw wear and an increase of claw disorders (Bergsten, 2001).

Alley floors in dairy farms are principally either solid concrete or slatted concrete (Telezhenko et al., 2009). Furthermore, the casting design and the patterning of a floor surface could be of several different types; smooth, tamped or grooved (Phillips, 2010). Solid concrete is the most commonly used floor material in dairy barns and the traditional concrete floor is casted with a smooth surface. This surface is often made with a wooden plank or a steel beam. The surface can also be made rougher with a broom, typical for slatted floors (House, 2011; Noordhuizen, 2012).

An optimal floor should provide a good grip, a compressible surface and good draining ability, which would help the cow to express normal locomotion. However, suboptimal floors are a major problem within modern free-stall farms and the floor quality in walking and standing areas has been strongly associated with animal welfare and health (Rushen and dePassille, 2009).One type of suboptimal floors is slippery floors, which will hinder normal locomotion behavior (Rushen and dePassille, 2009; Vander et al., 2005). The risks of injuries caused by suboptimal floors are suggested to be associated with four floor properties; the structure of the surface, amount of abrasion, compressibility and the potential of slip resistance (McKee and Dumelow, 1995). The purpose of grooving the floor is to increase the friction by different properties and thereby reduce slipperiness. One effect of correct grooving is an increased friction. However, if the floors become too abrasive there is a risk of over wear of the claws (Bergsten et al., 2015; Telezhenko et al., 2008).

\section{UDDER HEALTH}

The inflammation of the udder gland is one of the most common diseases of dairy cows and causes substantive costs (Petrovski et al., 2012). Frequent mastitis not only compromises the economic situation of a dairy herd but also reduces the satisfaction of the farmer with his work (Jansen et al., 2009) and affects animal welfare (Leslie 
and Petersson-Wolfe, 2012). Monitoring, that is the routine collection and analysis of information about the occurrence of mastitis and the evaluation of management practices, is a substantial part of the management of the udder health on dairy farms (Lam et al., 2011). Intramammary infections gained an importance's that are caused by pathogens whose reservoir is the environment of the cow. Usually, they are not considered to be contagious and are called environmental pathogens. Environmental mastitis is a multifactorial disease and it is considerably more complex to prevent (Krömker and Friedrich, 2009; Ruegg, 2012; Schukken et al., 1989; Smith, 1983).

Consequently, the recommended udder health programs were intensively specified, now covering not only the milking and the mastitis therapy but nearly the whole life of a dairy cow (genetics, housing, management, nutrition, milking, health status of the herd) (Krömker and Friedrich, 2009; National mastitis council, 2006). Udder health programs became so all-encompassing that fulfilling every point of the lists on a farm without prior cost-benefit-analysis may lead to considerably increased expenditures without appropriately reducing the losses (Morin et al., 1993).

The monitoring is a part of the current udder health programs (National mastitis council, 2006). The monitoring at the process level is recommended for improving and sustaining a good udder health on a herd level (Krömker, 2007; Schukken et al., 2003) and correlations between conducting monitoring activities (e.g., checking individual cows' cell count or the bacteriological investigation of clinical mastitis cases) and the improvement of the udder health of dairy herds (Jansen et al., 2009; National mastitis council, 2006). The monitoring is an essential part of mastitis control programs to achieve and maintain a good udder health on dairy farms in the long term. It is necessary for: routine evaluations of the herd health and performance status (Kelton, 2006; Krömker, 2007; Schukken et al., 2003), the continuous verification of the effectiveness of actions taken to improve the herd status (Green et al., 2012; Krömker, 2007) and, the early identification of emerging problems (Reneau and Kinsel, 1998).

Machine-milking induced alterations of the teat tissue can be used to evaluate the milking process. They may impair local defense mechanisms, and increase the risk of new intramammary infections (O'Shea, 1987). Mein et al. (2001), presented simple classification scheme to quantify the proportion of cows with an impaired teat condition and to assess the risk of new intramammary infections. There is influence of the teat condition on the risk of naturally occurring new intramammary infections, inflammatory responses and mastitis (Mein et al., 2001). For a dairy farmer, it is important to know the monetary loss due to mastitis on his specific farm, so that he can decide about investments in control measures. Losses due to mastitis are mainly determined by the reduction in milk yield (Hogeveen et al., 2011; Petrovski et al., 2012; Seegers et al., 2003).

\section{Udder hygiene}

Attempting to improve animal health status and product quality, the application of strict hygiene practices is a prerequisite (Noordhuizen, 2012). Infection of the mammary gland with environmental bacterial pathogens is the most significant udder health problem facing the dairy industry (Cook and Reineman, 2002). It is important to recognize that many opportunities for exposure to mastitis pathogens occur outside of the milking facility and all workers that have the ability to influence exposure should share accountability for mastitis control. Exposure to moisture, mud, and manure in cow housing areas can influence the rate of clinical mastitis. Rapid movement of animals for handling or milking often results in splattering of manure. Overcrowding results in excessive deposition of manure in housing areas that are designed for fewer animals. Manure handling, type of bedding and maintenance of cow beds all have major influences on hygiene (Ruegg, 2006).

SCORE 1

Free of dirt
SCORE 2

Slightly dirty $2-10 \%$ OF SURFACE AREA
SCORE 3

Moderately covered with dirt $10-30 \%$ OF SURFACE AREA
SCORE 4

Covered with caked on dirt $30 \%$ OF SURFACE AREA.

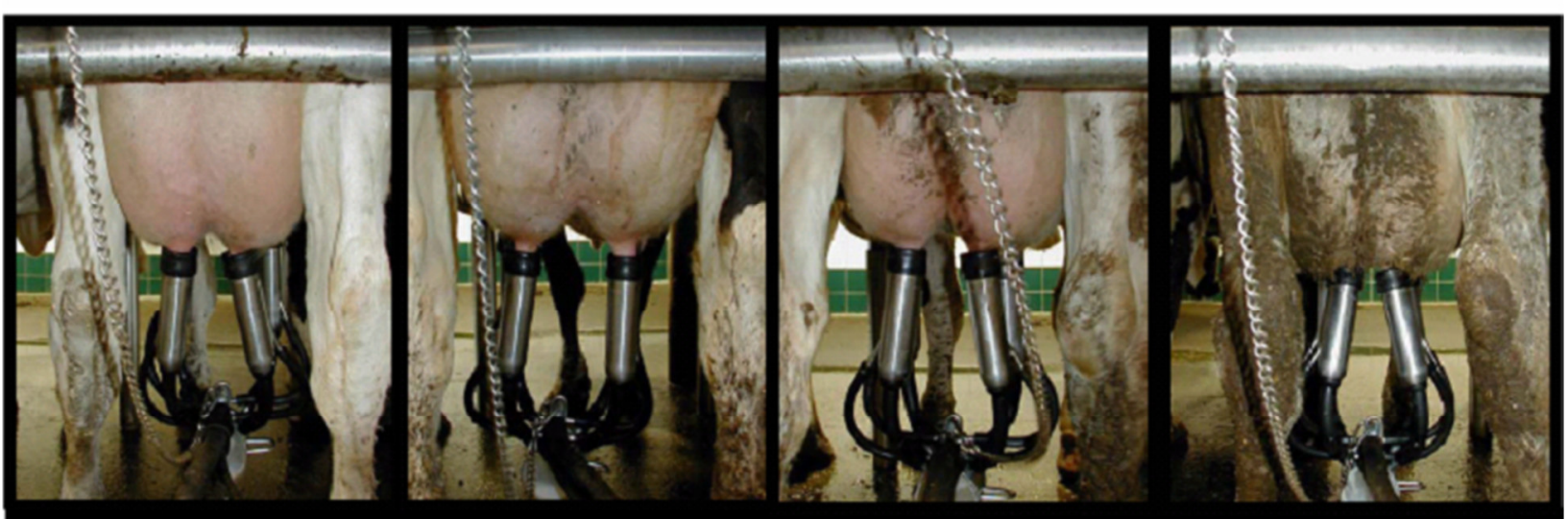

Figure 2: Udder hygiene scoring (Cook and Reineman, 2002). 


\section{Teat end callosity scoring}

Maintenance of healthy teat skin and teat-ends is a key part of any effective mastitis program. Changes to teat tissue, particularly the skin of the barrel, teat-end, and teat canal, alter the risk of new mastitis infections. Instruments and measurement techniques used to assess the condition of teat tissue include changes in teat thickness with a modified cutimeter, ultrasonography, sub-cutaneous oxygen tension, and pulse oximetry (Maltz et al., 2000; Hamann, 1987). Visual assessment of teats, comparison with photographs, and scoring schemes in nominal categories are the most common methods. Faults in milking machines or milking management are the primary cause of short-term changes in color, firmness, thickness or swelling of teats, or degree of openness of the teat orifice (Neijenhuis et al., 2001). Healthy teat skin is coated with a protective mantel of fatty acids that are derived from the dermal layer and which retard the growth of bacterial pathogens. When exposed to cold, wet and windy conditions, the skin of machine-milked teats often becomes scaly, irritated or chapped (broken skin) and the protective surface coating may be removed, thereby allowing colonization of pathogens such as Staphylococcus aureus (Fox, 1995; Nickerson, 1998).

Mud, as it dries, draws moisture from the skin with a consequent loss of elasticity of the teat skin. Chemical irritation associated with disinfectant type or concentration, or inappropriate type or concentration of emollients, may exacerbate the effects of harsh weather conditions and promote teat chapping. Skin conditioners or emollients either reduce evaporation from the skin or act as humectants to maintain or improve the teat skin condition. The dryness of black teats tends to be over-estimated by observation alone. Evaluation is improved by lightly rubbing the teat skin with a finger. In the absence of cracks and sores, differences in skin condition classed as smooth or rough do not seem to influence new mastitis infection rates (Rasmussen and Larsen, 1998).

The degree of teat-end hyperkeratosis (roughness, cornification or callosity) is a dynamic condition. Status of teat-ends for an individual cow or herd can change within days, especially in regions subject to harsh weather conditions or sudden weather changes. Seasonal conditions may affect dryness and hardness of keratin. In the absence of unusually harsh weather conditions, however, changes in teat-end status occur over a period of 2-8 weeks. Teat-end hyperkeratosis may be exacerbated by disinfectants that cause chemical irritation to teat skin or may be improved by the use of a disinfectant with a high concentration of an effective emollient (Britt and Farnsworth, 1996; Timms, 1998).

Teat-end callosity can be scored in a very detailed manner (Neijenhuijs et al., 2001), a less detailed practical manner (with a 1-5 scale) and a simple practical manner (with a 1-3 scale). There are two criteria for determining teat-end callosity, a ring and thickening of tissue. The ring can be smooth or frayed. The thickening can be present or absent. The scoring method with lowest scores (1-2) being preferred and highest scores (3-4) being undesirable.(Mein et al., 2001; Neijenhuijs et al., 2001; Noordhuizen, 2012; Strapak et al., 2017).

\section{Score 1}

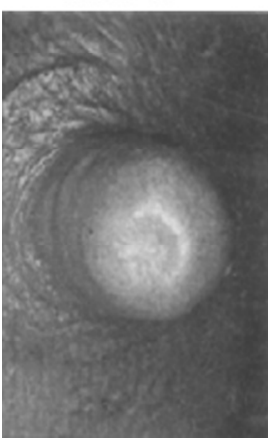

Score 2

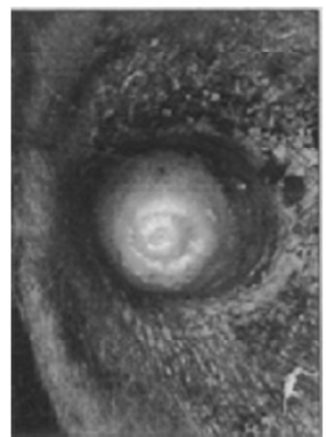

Score 3

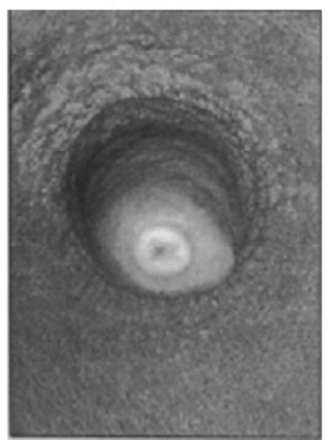

Score 4

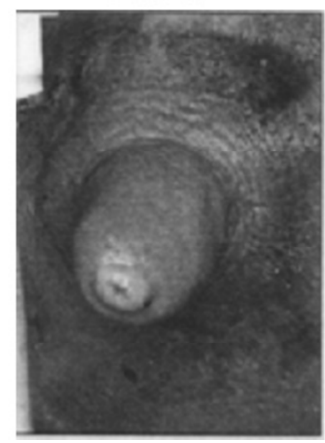

Score 5

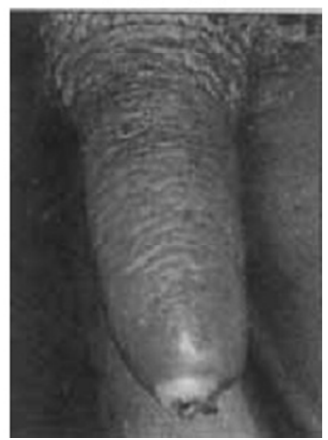

Figure 3: Teat end callosity scoring (Bradley, 2017; Noordhuizen, 2012).

Score 1: This is the perfect score. No edema after milking; around smooth ring and an indication for the least lesions caused by the milking machine; Score 2: The first signs of callosity are the round but thick rings around the teat base. The teat end is a little swollen; Score 3: The teat end is swollen; the ring is round but irregular and thick; Score 4: At the teat end one can observe the round thick ring, very edematous and eversed. There are not yet looking like warts; Score 5: This score is given to cases which look and feel like warts. The teat end is eversed and frayed (Bradley, 2017; Noordhuizen, 2012).

After milking the teat must leave the teat liner and cluster in a nearly dry condition. If the teat is wet, there is a problem with the speed at which the milk is transported to the milk container. The teats end up being washed in their own milk (Graeme et al., 2003). In this situation, bacteria can easily travel from one quarter to another. During milking, the teat liner can crawl up the teat towards the base, for example when wet udder preparation has been carried out and teats are wet when the cluster is attached. Another causal factor may be teat liners, which are too wide, long or short, or poor functioning of pulsators, too long a duration of milking, or a too high a vacuum. Cows with blue rings are often poorly milked. First lactation heifers and cows in early lactation are most frequently affected. Flat teats have been blocked in the teat liner, which can be painful for the cow. The 
cause is a too long phase (empty phase) of the pulsator, worn out teat liners, or teat liners, which are too hard or wide (Noordhuizen, 2012). Petechiae on the teat skinare caused by too high a vacuum under the teats or teat liners that are too large and finally the skin of the teat must feel flexible, without cracks or lesions. This can be achieved by applying good cosmetic teat-care products and good housing (cow comfort) (Cook and Reinemann, 2002; Cook, 2002).

\section{CLAW HEALTH}

\section{Functional (preventive) clawtrimming}

Functional trimming is a process used to restore function to the foot by returning overgrown claws to their normal size and proportions (Bell, 2009). Trimming should never be carried out in the month prior to calving. However, cows may be trimmed on the day of drying off and then again at two to three months after calving (when they are through the high risk period and will more easily recover from any claw lesions). A second option is to trim all cows twice a year (or more if needed), taking care not forget groups of animals, such as the pregnant maiden heifers With this option, ensure all cows are trimmed in one day or, at the most, over two consecutive days. A third option would be to trim cows on an individual basis, for example, cows with highly sensitive claws (Bell, 2009; DeLaval, 2006; Jan et al., 2015; Noordhuizen, 2012).

\section{Curative claw trimming}

Therapeutic trimmings are applied necessarily to correct and treat claw lesions (Bell, 2009). It is essential to trim claws of cows that show poor hind leg conformation, lameness or hoof deformities. Delaying trimming, in this situation, will exacerbate the situation and could result in problems with remaining claws, either by infection or by mechanical overload.Claw trimming should only be carried out using the appropriate tools and facilities. There exist several simple claw trimming facility options: Mobile, installation in a cubicle, fully equipped, standalone devices that can be placed anywhere on farm. To ensure cow welfare better, a herd claw trimming routine must be implemented. Trimming frequency should be every four months. An alternative option is claw trimming twice yearly. Older cows and repeat cases must be trimmed more frequently. To trim each cow just before drying off, as well as after peak milk yield (after 100 days lactation). If necessary, older cows and chronic cases must be claw trimmed more often (DeLaval, 2006; Jan et al., 2015; Noordhuizen, 2012).

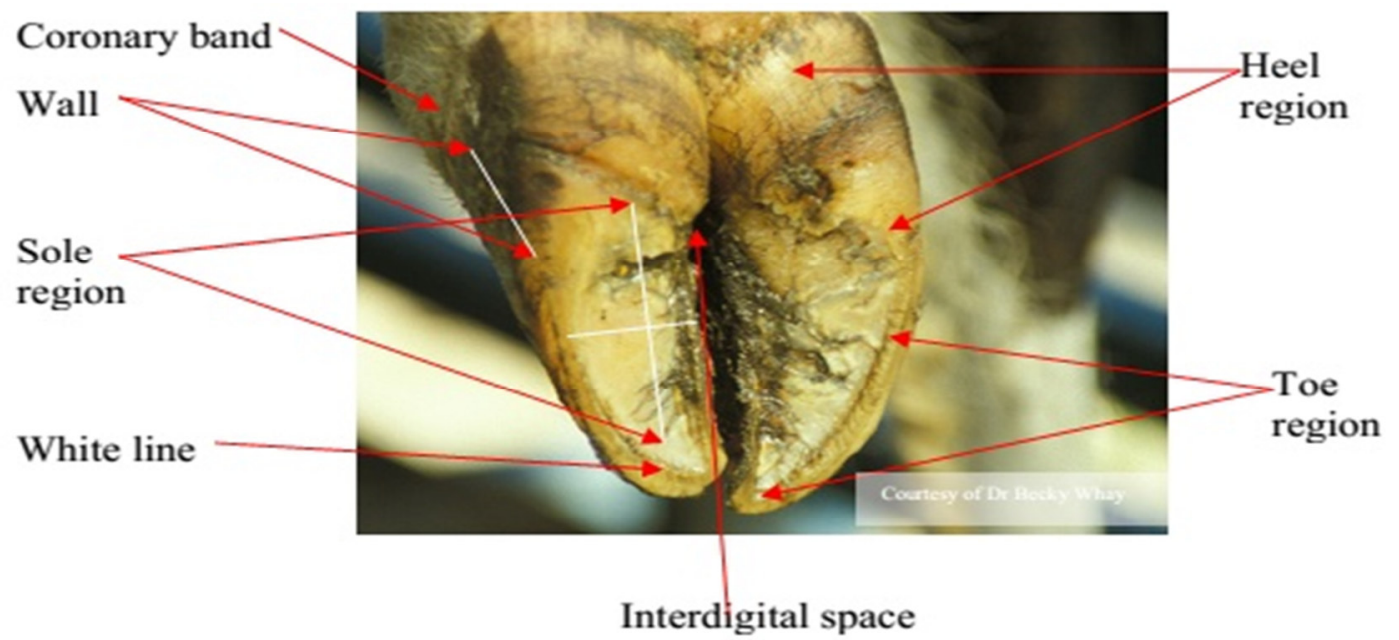

Figure 4a.Anatomical structure of claw (Bell, 2009). 


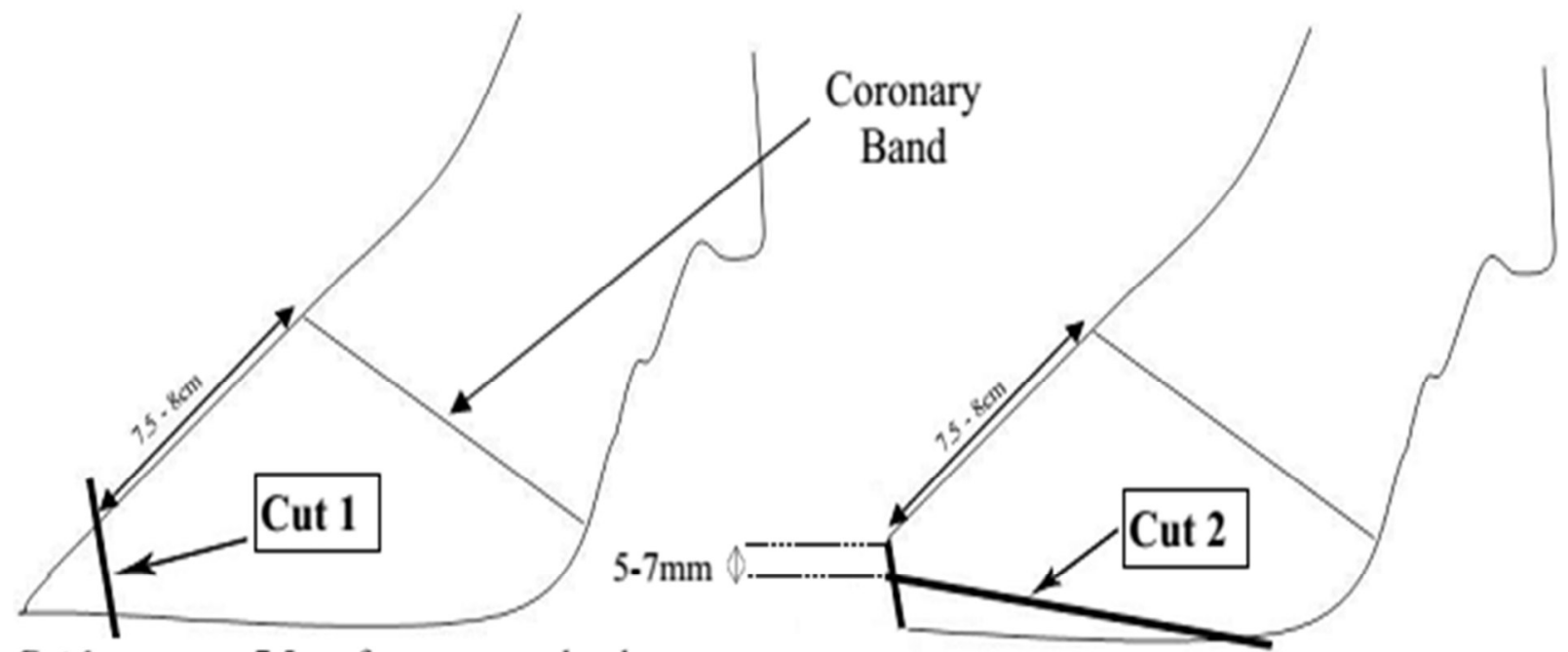

Cut 1 - measure $7.5 \mathrm{~cm}$ from coronary band (placing fingers in interdigital space). Some large cows need $8 \mathrm{~cm}$. Cut at an angle similar to that in the above diagram

Cut 2 - trim sole so $80 \mathrm{~mm}$ weight bearing (spare the heel), stopping before sole thinning ('give' on thumb pressure); trim until the white line just reappears at tip of the toe $(5-7 \mathrm{~mm}$ step at toe)

Figure 4b.Practical claw trimming instructions (Bell, 2009).

\section{CONCLUSION AND RECOMMENDATION}

Industrialization of animal farming and increasing international competition has led to selective breeding of high producing cows. As a result of this, attention shifted from curing single animals to prevention of disease on herd level. Permanent problem on dairy cattle farms is misunderstanding or even deliberate neglect of the importance of systematic application of biosecurity measures by employed and/or owners, in respect of isolating and layout of individual buildings, the introduction of newly acquired animals in the herd, footbaths functioning, as well as the technological way of doing repetitive tasks such as feeding or milking, use of medical materials and disposal of carcasses. Veterinarian must determine what level of risk on farm is willing to assume or accept and then design biosecurity plan accordingly to ensure that mitigation measures maintain the risk at an appropriate threshold.

It is essential that housing, feeding and general care are in balance with the needs of the animals.

The monitoring, that is the routine collection and analysis of information about the occurrence of mastitis and the evaluation of management practices, is a substantial part of the management of the udder health on dairy farms. Maintenance of healthy teat skin and teat-ends is a key part of any effective mastitis program. To ensure cow welfare better, a herd claw trimming routine must be implemented. Given the veterinarian's broad knowledge on many farm and disease related topics, combined with the need for farmers to invest in prevention, expanding veterinary advice within the scope of veterinary herd health management could be the road to the future.

Based on the above conclusions the recommendations are forwarded and includes; breeders have the primary responsibility to protect their own herds regarding introduction of the disease, control of movement, proper procedure and group housing of animals and sanitation. And also the stakeholders have to define and develop plan to keep potential pathogens for dairy herd health and production in cooperation with the veterinarian and the other professionals advising on organization and production technology. Moreover, the government should be enforced to establish policies on best practices of herd health management program which includes the vaccination protocols, observation of all animals for injury or signs of disease, complete, accurate, and reliable record keeping, protocols for the prevention, detection, and treatment of disease or injury, including lameness, protocols for pest control, training programs and protocols for animal handlers, individual animal identification and treatment records to ensure no animal is shipped prior to drug withdrawal times, ability to isolate new arrivals to the herd and calving protocols.

\section{REFERENCES}

Bell, N. (2009): Lameness control in dairy herds. Part 1 practical foot trimming by the Dutch method.www.nadis.org.uk.http://www.cattlelameness.org.uk/Course-materials.php.

Bergsten, C. (2001): Effects of conformation and management system on hoof and leg diseases and lameness in dairy cows. Veterinary Clinics of NorthAmerica: FoodAnimalPractice, 17:1-23. 
Bergsten, C.,Telezhenko, E. and Ventorp, M. (2015): Influence of soft or hard floors before and after first calving on dairy Heifer locomotion, claw and leg health. Veterinary Clinics of NorthAmerica: FoodAnimalPractice, 5:662-686.

Bradley, A.J. (2017): A veterinary perspective on udder health recording. Focus on clinical and sub -clinical mastitis. The global standard for livestock data.United kingdom.pp.1-9.

Britt, J.S. and Farnsworth, R. (1996): A system for evaluating teat anatomy, skin condition and teat ends. Proc. 35th Annual Meeting, National Mastitis Council, Nashville, TN, USA, pp 228-229.

Canadian Food Inspection Agency (2013): Biosecurity for Canadian Dairy Farms.Catalogue No.: A104-106/12013E.ISBN: 978-1-100-21858-8.pp.5-61.

Cook N.B. and Reinemann, D. (2002): A Tool Box for Assessing Cow, Udder and Teat Hygiene. Wisconsin.http://www.uwex.edu/milkquality/pdf/udder\%20hygiene\%20chart.pdf.pp.16.

Cook, A.J.C. (2013): Implementing biosecurity on dairy farms: Rewriting the cultural script. Guest Editorial. The Veterinary Journal. 197:118-119.

Cook, N. B. (2002): The influence of barn design on dairy cow hygiene, lameness, and udder health. pp.97-103

Debelie, N., Lenehan, J.J., Braam, C.R., Svennerstedt, B., Richardson, M. and Sonck, B. (2000): Durability of building materials and components in the agricultural environment, part III: Concrete structures. Journal of Agricultural Engineering Research. 76:3-16.

DeKruif, A., Opsomer, G. (2004): Integrated dairy herd health management as the basis for prevention. Vlaam.Diergeneeskd.Tijdschr.73:44-52.

DeLaval (2006): Efficient hoof management.www.delaval.com. pp.24-54.

Ellen, J., Angela, I. Dement, F. C., Faries , J. (1914): The Texas A\&M System.Biosecurity Practices for Dairy Operations pp.8-9.

Food and agriculture organization and international dairy federation (2011): Guide to good dairy farming practice. Animal production and health guidelines. No.8.Rome.pp.1-34.

Faust,M. A., Kinsel,M. L., and Kirkpatrick ,M. A. (2001): Characterizing Biosecurity, Health, and CullingDuring Dairy Herd Expansions.Journal of Dairy Science. 84:955-965.

Fox, L.K. (1995): Colonization of Staphylococcus aureus on chapped teat skin. Proc. $3^{\text {rd }}$ International Mastitis Seminar, Tel Aviv, Israel.pp II 6:51-55.

Graeme, A. M., David. M.D. W and Douglas, J. R. I. (2003): Effects of milking on teat-end hyperkeratosis: 1. Mechanical forces applied by the teat cup liner and responses of the teat.USA.pp.1-7.

Green, M. J. (2012): Opinions and practices of veterinarians and dairy farmers towards herd health management in the.Dairy Herd Health, CABI International, Walling ford. UK, The Veterinary Record.170:441.

Hamann, J. (1987): Effect of machine milking on teat-end condition. IDF Bulletin 215, pp. 46.

Haufe, H. C., L. Gygax, B. Steiner, K. Friedli, M. Stauffacher, and Wechsler, B. (2009): Influence of floor type in the walking area of cubicle housing systems on the behavior of dairy cows. Applied Animal Behaviour Science, 116:21 -27.

Hogeveen, H., Huijps, K., LAM, T.J.G.M. (2011): Economic aspects of mastitis: new developments. $N Z$ Veterinary Journal, 59:16-23.

House, J. (2011): A guide to dairy herd management. The university of Sydney new south wales, Australia.Journal of meat and livestock Australia limited.pp.32-47.

Hultgren, J. (2002): Foot/leg and udder health in relation to housing changes in Swedish dairy herds. Preventive veterinary medicine. 53:167-189.

James, B., Peter, D., Chris, H., Jon, H., Oli, M., John, R. (2013): Dairy herd health in practice.VetTimes.https://www.vettimes.co.uk.

Jan, K.S.,Paul, J. P.,Jennifer, A. S. (2015): Perspectives on the treatment of claw lesions in cattle.Veterinary Medicine: Research and Reports. USA. 2015:6 273-292

Jansen, J., Van den Borne, B., Renes, R., Van Schaik, G., Lam, T.J.G.M. and Leeuwis, C. (2009): Explaining mastitis incidence in Dutch dairy farming: The influence of farmers attitudes and behaviour', Preventive Veterinary Medicine.92:210-223.

Kelton, D.F. (2006): Epidemiology: a foundation for dairy production medicine. Vetrinary Clinic North America Food Animal Practice. 22:21-33.

Krömker, V. (2007):Euterkrankheiten, in: Krömker, V. (Ed.), KurzesLehrbuchMilchkunde und Milchhygiene. Parey, Stuttgart, pp. 47-74.

Krömker, V., Friedrich, J. (2009):Eutergesundheitoptimieren - bakterielleInfektionen der Milchdrüse des Rindes - Leitkeime und Bekämpfungsstrategien. RundschaufürFleischhygiene und Lebensmittelüberwachung.pp.68.

Lam, T., VanVeersen, J., Sampimon, O., Riekerink, R.G.M.O. (2011): On-farm udder health monitoring. TierarztlPraxAusg G GrosstiereNutztiere.2:95-100.

LeBlanc, S.J., Lissemore, K.D., Kelton, D.F., Duffield, T.F. and Leslie, K.E. (2006): Major advances in disease 
prevention in dairy cattle, Journal of Dairy Science. 89:1267-1279.

Leppala, J. (2016): Systematic risk management on farms. Doctoral Dissertation. Alto university publication series.Helsinki.pp.2-64.

Leslie, K.E., Petersson-Wolfe, C.S. (2012): Assessment and management of pain in dairy cows with clinical mastitis. Veterinary Clinic North America Food Animal Practice.28:289-305.

Maltz, E. D.J. Reinemann and Davis, M.A. (2000): Blood flow and oxygen concentration of teat- end tissue before and after machine milking. Paper \#003012. ASAE Annual International Meeting, Milwaukee, Wisconsin, pp 10-13.

McKee, C.I. and Dumelow, J. (1995): A review of the factors involved in developing effective non-slip floors for pigs. Journal of Agricultural Engineering Research. 60:35-42.

Mein, G.A., Neijenhuis, F., Morgan, W.F., Reinemann, D.J., Hillerton, J.E.,Baines, J.R., Ohnstad, I., Rasmussen, M.D., Timms, L., Britt, J.S., Farnsworth,R., Cook, N., Hemling, T. (2001): Evaluation of bovine teat condition in commercial dairy herds - non-infectious factors, in: National Mastitis Council (NMC) (Ed.), Proceedings of the 2nd international symposium on mastitis and milk quality, pp. 347-351.

More, S.J. (2008): Herd health prompts concern over international competitiveness. Irish veterinary journal . 61:92-100

Morin, D.E., Petersen, G.C., Whitmore, H.L., Hungerford, L.L., Hinton, R.A. (1993): Economic analysis of a mastitis monitoring and control program in four dairy herds. Journal of American Veterinary Medicine Association. 202:540-548.

National Mastitis Council (2006): National Mastitis Council recommended mastitis control program.http://www.nmconline.org/docs/NMCchecklistInt.pdf.

Neijenhuis, F., H. W. Barkema, H. Hogeveen, and J. P. T. M. Noordhuizen. (2001): Relationship between teatend callosity and occurrence of clinical mastitis. Journal of Dairy Science. 84:2664-2672.

Nickerson, S. (1998): Teat end interactions with germicides. Proc. 37th Annual Meeting, National Mastitis Council, St Louis, MI. pp. 67-73.

Noordhuizen, J. (2012): Dairy Herd Health and Management .A guide for veterinarians and dairy professionals. ISBN 978-1-899043-36-1.pp.5-412.

Norberg,S. (2012): Effects of rubber ralley flooring on cow locomotion and welfare.Swidish University Agricultural science.Department of Animal Nutrition and Management.Degree project.pp.3-80.

O'shea, J. (1987): Machine milking and mastitis. Section 2: Machine milking factors affecting mastitis - a literature review. Bulletin of International Dairy Fed 215:5-32.

Petrovski, K.R., Trajcev, M., Buneski, G. (2012): A review of the factors affecting the costs of bovine mastitis: review article. Journal of South African Veterinary Association. 77:52-60.

Phillips, C.J.C. \& Morris, I.D. (2001): The locomotion of dairy cows on floor surfaces with different frictional properties. Journal of Dairy Science. 84:623-628.

Phillips, C.J.C. (2010): Principles of cattle production. $2^{\text {nd }}$ edition. Cambridge: Cambridge University Press. 39:96-107.

Platz, S., Ahrens, F., Brendel, J., Meyer, H. H. D., Erhard, M. H. (2008): What happens with cow behavior when replacing concrete slatted floor by rubber coating: A case study. Journal of Dairy Science. 91:999-1004.

Rasmussen, M. D. and H. D. Larsen. (1998): The effect of post milking teat dip and suckling on teat skin condition, bacterial colonization, and udder health. Acta veterinary scandnavian. 39:443-452.

Reneau, J.K., Kinsel, M.L. (1998): Record systems and herd monitoring in productionoriented health management programs, in: Radostis, O.M. (Ed.), Herd health, food animal production medicine. WB Saunders, Philadelphia, pp. 107-146.

Ruegg, P.L. (2012): New perspectives in udder health management. Veterinary Clinic North American Food Animal Practice.28:149-163.

Ruegg, P.L. (2006): The role of hygiene in efficient milking.WCDS.Advances in dairy technology. 18:85-293.

Rushen, J. and de Passille, A.M. (2009): Flooring Options to Minimize Lameness and Optimize Welfare. Advances in Dairy Technology. 21:293-301.

Schukken, Y.H., Grommers, F.J., Van De Geer, D., Brand, A. (1989): Incidence of clinical mastitis on farms with low somatic cell counts in bulk milk. Veterinary Research.125:60-63.

Schukken, Y.H., Wilson, D.J., Welcome, F., Garrison-Tikofsky, L., Gonzalez,R.N. (2003): Monitoring udder health and milk quality using somatic cell counts. Veterinary Research.34:579-596.

Seegers, H., Fourichon, C., Beaudeau, F. (2003): Production effects related to mastitis and mastitis economics in dairy cattle herds. Veterinary Research.34: 475-491

Smith, K.L. (1983): Mastitis control: a discussion. Journal of Dairy Science. 66:1790-1794.

Stankovic.B, Hristov.S, Zlatanovic.Z, Bojkovsk.J, Maksimovic.N. (2016): Sustainability and efficiency dairy farms biosecurity plans. Agro-knowledge journal.4:437-453.

Strapák P., Strapáková E., Rušinová M., Szencziová I. (2017): Thinflence of milking on the tea t canal of dairy 
cows determined by ultrasonographic measurements. Czech Journal of Animal Science. 62:75-81.

Tatiana, F. A. (2017):Biosecurity In Dairy Farms.Facultat de veterinaria.Barcelona.pp.1-2.

Telezhenko, E. and Bergsten, C. (2005): Influence of floor type on the locomotion of dairy cows. Applied Animal Behaviour Science. 93:183-197.

Telezhenko, E., Bergsten, C., Magnusson, M. and Nilsson, C. (2009): Effect of different flooring systems on claw conformation of dairy cows. Journal of Dairy Science. 92:2625-2633.

Telezhenko, E., Bergsten, C., Magnusson, M., Ventorp, M. and Nilsson, C. (2008): Effect of different flooring systems on weight and pressure distribution on claws of dairy cows. Journal of DairyScience. 91:18741884.

Telezhenko, E., Magnusson, M. and Bergsten, C. (2017): Gait of dairy cows on floors with different slipperiness. Journal of Dairy Science. 100: 6494-6503.

Timms, L. (1998): A Year in the Life of a Teat End. Proc. 37th Annual Meeting, National Mastitis Council, St Louis, MI. pp 74-77.

Vander ,T.P.P.J., Metz, J.H.M., Noordhuizen-Stassen, E.N., Back, W., Braam, C.R. and Weijs, W.A. (2005): Frictional forces required for unrestrained locomotion in dairy cattle. Journal of DairyScience. 88:615-624.

Veterinary development council (2012): The veterinary development council report.pp.23-26.

Wallace, L.R. (2003): Practical and Sensible Dairy Farm Biosecurity. Proceedings of the $6^{\text {th }}$ Western Dairy Management Conference.Reno, NV.pp.202-206.

Whitaker, D. A., Kelly, J. M., Smith, S. (2000): Disposal and disease rates in 340 British dairy herds.Veterinary Record. 146:363-367. 